\title{
Editorial
}

\section{Apurar a vida até chegar à borra}

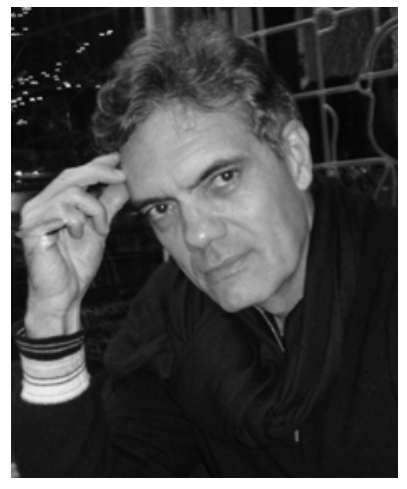

Marco Antonio Guimarães da Silva

Dizem que as pessoas costumam priorizar as leituras que fazem dos cadernos de jornais pelas idades que tem: até os vinte e poucos anos, se preocupam em dar uma olhadela na parte do cinema e de shows; a partir dos trinta, já se interessam pelos temas políticos; e a partir dos sessenta, vão direto para o necrológico, para ver se há ali um convite para o enterro de algum amigo ou conhecido ou quem sabe até mesmo o anúncio de sua própria morte, considerando-se aqui a versão mediúnica da coisa.

Mas há algumas exceçôes para essa divisão didática e cronológica da leitura de cadernos dos jornais que acabo de fazer. Julgo poder me incluir entre elas. Ainda não tinha chegado aos 10 anos e já era leitor assíduo da coluna que Nelson Rodrigues escrevia para O Jornal ou para a Última Hora.

Não sou um Rodrigueano de carteirinha, mas o estilo de Nelson Rodrigues me encantava (para mim ele foi o melhor cronista que o nosso país já nos deu) e viria a ser o responsável pela minha rotina diária de ler os jornais de cabo a rabo. Uma desgraçada rotina que se perpetuou em mim. Digo desgraçada rotina, porque a minha blindagem às noticias ruins foi, com o passar dos anos, diminuindo e tornei-me presa fácil de sentimentos que me levaram, ao longo do tempo, da indignaçáa contida a um estado apoplético, quando vejo os descalabros veiculados na nossa imprensa. Tudo isso reflexo de uma sociedade quase que integralmente corrupta e corruptora; felizmente também aqui com exceçôes. Mas, em algumas situaçóes, as noticias, ainda que desastrosas, vem acompanhadas de um boa dose de humor; humor negro, mas humor.

E não pude conter um irônico sorriso quando li a seguinte notícia: "A nota do Brasil no Índice de Percepção de Corrup- ção, divulgado nesta quarta-feira pela ONG Transparência Internacional, evoluiu de 3,7 para 3,8 (escala de 0 a 10), na comparação com o ano passado". A Nova Zelândia, com nota 9,5 é a mais bem colocada no ranking e a Somália e Coréia do Norte figuram nos últimos lugares, ambos com nota 1,0.

No meu saudoso e longínquo tempo de aluno de escola primária, o modernismo pedagógico ainda não havia transformado os conceitos numéricos em conceitos qualitativos, representados por letras. Lembro-me que qualquer nota abaixo de sete era considerada nota ruim e podia levar-nos à reprovação; já que a recuperação, mecanismo criado para dar mais uma chance aos desditosos que não cumpriram seus deveres de casa, também ainda não havia dado a sua cara.

Atualmente, não se pode deixar de reconhecer que há um certo combate das autoridades constituídas aos corruptos e até algumas açôes que os levam à cadeia. Mas não se pode deixar de notar uma coisa: a maioria dos movimentos que caçaram os delinquentes de paletó e gravata foram frutos de denuncias da imprensa. Eu me pergunto: os órgáos de inteligência que assessoram o governo e que conseguiam, na época da ditadura, monitorar, prender e caçar os "comunistas", não poderiam, antecipando-se às denuncias da imprensa, fazer o mesmo com relaçáo a essas ratazanas? Ou teriam que esperar pela edição da próxima Veja, da Época, ou de qualquer outro periódico?

O fato é que, com essa nota, não poderíamos nem mesmo entrar para uma turma de recuperação. Quem sabe no próximo ano? Ou talvez no próximo século? Ou talvez nunca? Mas não se exaspere, o budismo, nas palavras de Borges, nos diz: é preciso apurar a vida até chegar à borra, depois se desenganar dela; mas nunca sem conhecê-la. 